\title{
PEMBUATAN SIMPING HERBAL DARI DAUN BELUNTAS (Plucea Indica (L) Less) UNTUK PERAWATAN KESEHATAN
}

\author{
Egi Prastika Jayadinata ${ }^{1}$, Susi Andriani ${ }^{2 *}$, Dewi Ratnasari ${ }^{3}$ \\ 1,2,3 Sekolah Tinggi Ilmu Kesehatan Holistik \\ *Korespondensi: Jl. Veteran No.272 Ciseureuh Purwakarta, Email: susi_andriani08@yahoo.co.id
}

\begin{abstract}
ABSTRAK
Tujuan Penelitian: Penelitian ini bertujuan untuk menyediakan sediaan jadi cemilan sehat yang dapat digunakan oleh masyarakat untuk perawatan kesehatan.

Metode: Dalam penelitian ini dilakukannya pendekatan kualitatif dengan metode penelitian tindakan yang dikembangkan dari penelitian sebelumnya mengenai khasiat daun Beluntas (Plucea Indica (L) Less). Dalam penelitian ini peneliti membuat cemilan sehat dari daun Beluntas (Plucea Indica (L) Less) dalam bentuk simping melalui proses infusa dengan pelarut air kemudian dijadikan bahan campuran pada bahan dasar simping yaitu tepung tapioka dan tepung terigu. Simping ini dibuat dengan mencampurkan 1 liter air infusa daun Beluntas (Plucea Indica (L) Less) dengan tepung tapioka $1,25 \mathrm{~kg}$, tepung terigu $0,25 \mathrm{~kg}$, santan $240 \mathrm{ml}$, dan garam $37 \mathrm{~g}$.

Hasil: Pengujian organoleptis sediaan dilakukan selama 21 hari dengan hasil yang menunjukan bahwa tidak ada perubahan negatif yang terjadi dari bentuk, warna, bau, rasa, maupun ada tidaknya pertumbuhan jamur.

Simpulan: Dalam penelitian ini peneliti berhasil membuat cemilan sehat dalam bentuk cemilan sehat dapat bertahan selama 3 minggu.
\end{abstract}

Kata kunci: daun beluntas, cemilan sehat, simping

\section{ABSTRACT}

Objective: This research aims to provide healthy snacks so that preparations can be used by the community for health care.

Method: In this research he did approach a qualitative research method of action developed from previous research on efficacy of leaf Beluntas (Plucea Indica (L) Less). In this study researchers make healthy snacks from the leaves of Beluntas (Plucea Indica (L) Less) in the form of the scallop through the process of with infusa solvent water was mixed on basic material i.e. simping tapioca flour and flour wheat flour. Simping is made by mixing 1 liter water infusa leaf Beluntas (Plucea Indica (L) Less) with tapioca flour $1.25 \mathrm{~kg}, 0.25 \mathrm{~kg}$ of wheat flour, coconut milk $240 \mathrm{ml}$, and $37 \mathrm{~g} \mathrm{of}$ salt.

Result: The resultof theorganoleptis preparations testing done for 21 days with the results show that there is no negative changes that occurred from the shape, color, smell, taste, or whether or not there is mold growth.

Conclusion: In this study the researchers managed to make healthy snacks in the shape of a healthy snack can last for 3 weeks.

Keywords: leaf beluntas, healthy snacks, simping

\section{PENDAHULUAN}

Tanaman Beluntas (Plucea Indica (L) Less) merupakan salah satu tanaman obat tradisional yang cukup tersebar luas di Indonesia. Tanaman ini termasuk jenis semak atau setengah semak. Tumbuh tegak dengan tinggi mencapai 2 meter. Tanaman ini tumbuh secara liar dan terdapat di tanah yang tandus yang kurang terurus. Sebagian orang memanfaatkan tanaman ini sebagai pagar pekarangan. Golongan senyawa aktif yang teridentifikasi dalam daun beluntas antara lain fenol hidrokuinon, tanin, alkaloid, steroid dan minyak atsiri.

Senyawa tanin bersifat sebagai astringent, mekanisme tanin sebagai astringen adalah dengan menciutkan permukaan usus atau zat yang bersifat proteksi terhadap mukosa usus dan dapat menggumpalkan protein. Oleh Karena itu 
senyawa tanin dapat membantu menghentikan diare. ${ }^{1}$ Hasil penelitian lain menyebutkan bahwa kandungan kimia yang ada pada daun Beluntas (Plucea Indica (L) Less) yaitu flavonoid mempunyai aktivitas antibakteri terhadap Staphylococcus aureus yang dapat menimbulkan bau badan. ${ }^{2}$

Secara ilmiah, minyak atsiri daun Beluntas (Plucea Indica (L) Less) terbukti memiliki daya hambat terhadap Candida albicans yang dapat menyebabkan keputihan. Kandungan kimia minyak atsiri daun Beluntas (Plucea Indica (L) Less) terdiri atas Caryophyllene, Isocaryophyllene, serta senyawa derivat azulene, dan naphthalene. ${ }^{3}$

Pengetahuan masyarakat tentang khasiat daun beluntas (Pluchea Indica (L) Less) sangat kurang, sehingga banyak daun beluntas di lingkungan sekitar rumah hanya dijadikan pagar pekarangan. Hal ini sangat disayangkan, ada banyak daun beluntas disekitar lingkungan masyarakat yang seakan-akan tidak berguna. Untuk itu, penulis tertarik memanfaatkan daun beluntas tersebut dijadikan cemilan sehat untuk perawatan kesehatan yang merakyat yaitu simping.

Simping merupakan makanan khas kota Purwakarta, berbentuk lembaran pipih, renyah. Simping bisa dikonsumsi oleh beberapa kalangan dari mulai anak-anak, remaja, dewasa, bahkan sampai orang tua. Simping mempunyai bermacam-macam rasa tidak hanya rasa kencur yang sering dijadikan oleh-oleh khas Purwakarta, namun ada diantaranya rasa cabe, susu, pisang, keju, dan ada juga simping rasa cokelat.

Penulis memilih simping dalam Tugas Akhir sebagai cemilan sehat untuk perawatan kesehatan, misalnya untuk mengatasi bau badan, keputihan, diare, dan deman. Selain itu, karena simping dalam proses pembuatannya cukup mudah dan praktis, bentuknya menarik, bisa dikonsumsi berbagai kalangan mulai dari anak-anak, remaja, dewasa hingga orang tua. Selain itu, Simping juga sudah terkenal di berbagai daerah Jawa Barat khususnya di Purwakarta.

Dari penelitian sebelumnya belum ada peneliti yang membuat sediaan simping dari daun Beluntas (Plucea Indica (L) Less) sebagai cemilan sehat untuk perawatan kesehatan, maka penulis tertarik untuk membuat tugas akhir dalam sediaan cemilan sehat dari daun Beluntas (Plucea Indica (L) Less) yang berjudul : "Pembuatan Simping Herbal dari Daun Beluntas (Plucea Indica (L) Less) Untuk Perawatan Kesehatan".

\section{METODE PENELITIAN}

Penelitian ini dilakukan dengan pendekatan kualitatif dan dengan metode penelitian tindakan yang dikembangkan dari penelitian sebelumnya mengenai khasiat daun Beluntas (Plucea Indica (L) Less) untuk pencegahan beberapa bakteri penyebab timbulnya berbagai penyakit pada hewan uji coba yang dimaksudkan untuk perawatan kesehatan.

Pada penelitian ini, jenis tumbuhan yang akan dibuat adalah berupa makanan ringan dari daun beluntas (Plucea Indica (L) Less) yang berkhasiat untuk perawatan kesehatan dalam bentuk cemilan sehat yaitu simping. Makanan ini dikenal sebagai makanan khas daerah kabupaten Purwakarta. Ada beberapa tahapan dalam pembuatan simping dari daun beluntas ini, salah satu diantaranya pengumpulan bahan, penyiapan bahan yang bagus untuk dijadikan simping, dan proses pembuatan sehingga menghasilkan simping yang enak.

Lokasi yang dijadikan dalam pengumpulan bahan yakni di daerah Cimaung Kabupaten Purwakarta. Di daerah tersebut tanaman Beluntas (Plucea Indica (L) Less) hanya dijadikan pagar pekarangan, akan tetapi ada beberapa orang diantaranya memanfaatkan daunnya untuk dijadikan lalapan.

\section{HASIL PENELITIAN \\ Hasil Uji Organoleptis}

Simping dari daun Beluntas (Plucea Indica (L) Less) telah selesai dibuat lalu sediaan tersebut dilakukan pengujian organoleptis dengan mengamati bentuk, warna, bau, rasa dan tumbuhnya jamur selama 3 minggu dengan pengamatan setiap 3 hari sekali disim pan dalam penyimpanan yang sama, yaitu dalam suhu ruangan 20 $25^{\circ}$. Kemudian hasil pengamatan tersebut dicatat dalam bentuk tabel 4.1 dan seterusnya. 
Journal of Holistic and Health Sciences

Vol.2, No.1, Januari-juni $2018 \mid \mathbf{3 2}$

Tabel 4.1 Pengamatan Sediaan 3 Hari Pertama

\begin{tabular}{|c|c|c|c|c|c|}
\hline Suhu & $\begin{array}{c}\text { Bentuk } \\
\text { Sediaan }\end{array}$ & Warna & Bau & Rasa & Jamur \\
\hline $\begin{array}{c}\text { Suhu } \\
\text { Ruangan } \\
20-25^{\circ} \mathrm{C}\end{array}$ & Simping & Putih keabu-abuan & $\begin{array}{c}\text { Bau Khas Daun Beluntas } \\
\text { dan Tepung }\end{array}$ & Asin & $\begin{array}{c}\text { Tidak Tumbuh } \\
\text { Jamur }\end{array}$ \\
\hline
\end{tabular}

Tabel 4.1 menunjukan bahwa pada tiga hari pertama, pada hari Senin, 14 Agustus 2017 sediaan yang disimpan dalam suhu ruangan tidak menunjukan perubahan yang signifikan dalam hal bentuk, rasa, bau, warna, dan tumbuhnya jamur.

Tabel 4.2 Pengamatan Sediaan 3 Hari Kedua

\begin{tabular}{|c|c|c|c|c|c|}
\hline Suhu & $\begin{array}{c}\text { Bentuk } \\
\text { Sediaan }\end{array}$ & Warna & Bau & Jamur \\
\hline $\begin{array}{c}\text { Suhu } \\
\text { Ruangan } \\
20-25^{\circ} \mathrm{C}\end{array}$ & Simping & Putih keabu-abuan & $\begin{array}{c}\text { Bau Khas Daun Beluntas } \\
\text { dan Tepung }\end{array}$ & Asin & $\begin{array}{c}\text { Tidak Tumbuh } \\
\text { Jamur }\end{array}$ \\
\hline
\end{tabular}

Tabel 4.2 menunjukan bahwa pada tiga hari kedua, pada hari Jumat, 18 Agustus 2017 sediaan yang disimpan dalam suhu ruangan tidak menunjukan perubahan yang signifikan dalam hal bentuk, rasa, bau, warna, dan tumbuhnya jamur.

Tabel 4.3 Pengamatan Sediaan 3 Hari Ketiga

\begin{tabular}{|c|c|c|c|c|c|}
\hline Suhu & $\begin{array}{c}\text { Bentuk } \\
\text { Sediaan }\end{array}$ & Warna & Bau & Rasa & Jamur \\
\hline $\begin{array}{c}\text { Suhu } \\
\text { Ruangan } \\
20-25^{\circ} \mathrm{C}\end{array}$ & Simping & Putih keabu-abuan & $\begin{array}{c}\text { Bau Khas Daun Beluntas } \\
\text { dan Tepung }\end{array}$ & Asin & $\begin{array}{c}\text { Tidak Tumbuh } \\
\text { Jamur }\end{array}$ \\
\hline
\end{tabular}

Tabel 4.3 menunjukan bahwa pada tiga hari ketiga, pada hari Senin, 21 Agustus 2017 sediaan yang disimpan dalam suhu ruangan tidak menunjukan perubahan yang signifikan dalam hal bentuk, rasa, bau, warna, dan tumbuhnya jamur.

Tabel 4.4 Pengamatan Sediaan 3 Hari Keempat

\begin{tabular}{|c|c|c|c|c|c|}
\hline Suhu & $\begin{array}{c}\text { Bentuk } \\
\text { Sediaan }\end{array}$ & Warna & Bau & Rasa & Jamur \\
\hline $\begin{array}{c}\text { Suhu } \\
\text { Ruangan } \\
20-25^{\circ} \mathrm{C}\end{array}$ & Simping & Putih keabu-abuan & $\begin{array}{c}\text { Bau Khas Daun Beluntas } \\
\text { dan Tepung }\end{array}$ & Asin & $\begin{array}{c}\text { Tidak Tumbuh } \\
\text { Jamur }\end{array}$ \\
\hline
\end{tabular}

Tabel 4.4 menunjukan bahwa pada tiga hari keempat, pada hari Kamis, 24 Agustus 2017 sediaan yang disimpan dalam suhu ruangan tidak menunjukan perubahan yang signifikan dalam hal bentuk, rasa, bau, warna, dan tumbuhnya jamur.

Tabel 4.5 Pengamatan Sediaan 3 Hari Kelima

\begin{tabular}{|c|c|c|c|c|c|}
\hline Suhu & $\begin{array}{c}\text { Bentuk } \\
\text { Sediaan }\end{array}$ & Warna & Bau & Rasa & Jamur \\
\hline $\begin{array}{c}\text { Suhu } \\
\text { Ruangan } \\
20-25^{\circ} \mathrm{C}\end{array}$ & Simping & Putih keabu-abuan & $\begin{array}{c}\text { Bau Khas Daun Beluntas } \\
\text { dan Tepung }\end{array}$ & Asin & $\begin{array}{c}\text { Tidak Tumbuh } \\
\text { Jamur }\end{array}$ \\
\hline
\end{tabular}

Tabel 4.5 menunjukan bahwa pada tiga hari kelima, pada hari Senin, 28 Agustus 2017 sediaan yang disimpan dalam suhu ruangan tidak menunjukan perubahan yang signifikan dalam hal bentuk, rasa, bau, warna, dan tumbuhnya jamur. 
Journal of Holistic and Health Sciences

Vol.2, No.1, Januari-jun i 2018 |33

Tabel 4.6 Pengamatan Sediaan 3 Hari Keenam

\begin{tabular}{|c|c|c|c|c|c|}
\hline Suhu & $\begin{array}{c}\text { Bentuk } \\
\text { Sediaan }\end{array}$ & Warna & Bau & Rasa & Jamur \\
\hline $\begin{array}{c}\text { Suhu } \\
\text { Ruangan } \\
20-25^{\circ} \mathrm{C}\end{array}$ & Simping & Putih keabu-abuan & $\begin{array}{c}\text { Bau Khas Daun Beluntas } \\
\text { dan Tepung }\end{array}$ & Asin & $\begin{array}{c}\text { Tidak Tumbuh } \\
\text { Jamur }\end{array}$ \\
\hline
\end{tabular}

Tabel 4.6 menunjukan bahwa pada tiga hari keenam, pada hari Kamis, 31 Agustus 2017 sediaan yang disimpan dalam suhu ruangan tidak menunjukan perubahan yang signifikan dalam hal bentuk, rasa, bau, warna, dan tumbuhnya jamur.

Berdasarkan pengujian organoleptis selama tiga minggu berturut-turut dapat disimpulkan bahwa dari tabel 4.1-4.6 menunjukan bahwa hasil pengujian organoleptis yang dilakukan peneliti dalam suhu ruangan $20-25^{\circ} \mathrm{C}$ tidak timbul perubahan yang signifikan dalam hal bentuk sediaan, warna, rasa, bau dan tumbuhnya jamur. Hal ini terjadi diperkirakan karena dari proses pengambilan, dan penyiapan bahan baku serta sampai proses pembuatan yang teratur, maka dari itu tidak adanya perubahan negatif dalam sediaan yang dibuat.

Adapun hasil penelitian ini didapatkan cemilan sehat berupa simping yaitu sebagai berikut:

Tabel 4.7 Hasil Simping dari Daun Beluntas

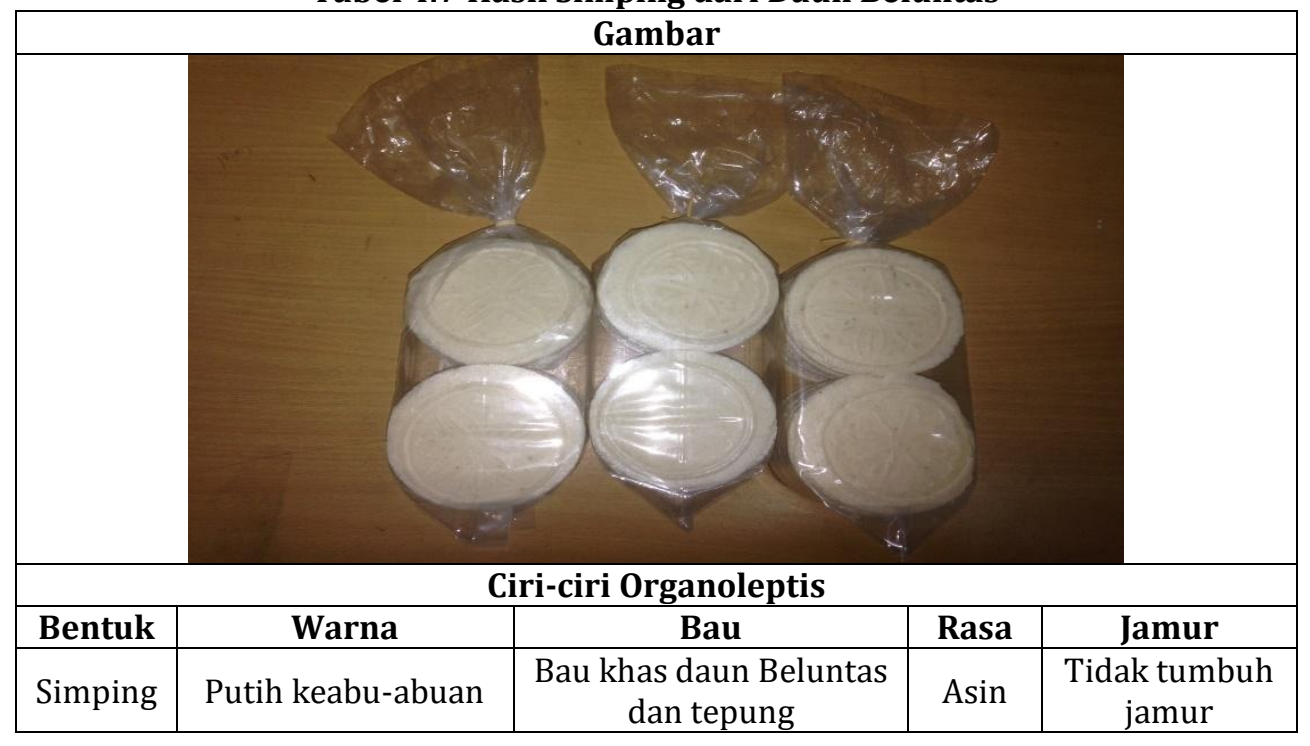

1) Hasil simping yang didapat 900 gram yang dihasilkan dari 1liter air infusa daun beluntas, tepung tapioka $1,25 \mathrm{~kg}$, tepung terigu $0,25 \mathrm{~kg}$, santan sebanyak $240 \mathrm{ml}$, dan garam $37 \mathrm{gr}$.

2) Berat simping akhir satu toples 150gram dengan banyaknya 6 buah toples.

\section{PEMBAHASAN}

Daun Beluntas (Plucea Indica (L) Less) yang digunakan dalam penelitian ini diperoleh di daerah Cimaung Kabupaten Purwakarta. Proses pengambilan daun beluntas (Plucea Indica (L) Less) sendiri dengan cara dipetik satu persatu dari batangnya. Daun Beluntas (Plucea Indica (L)
Less) yang dipetik merupakan daun yang berwarna hijau tua yang merupakan daun yang cukup tua dan cukup tebal, menandakan bahwa daun tersebut sudah cukup tua untuk dipetik. Daun Beluntas (Plucea Indica (L) Less) yang telah dipetik lalu dibersihkan dengan cara mencucinya dengan air mengalir, pastikan semua debu dan kotoran yang menempel pada daun tersebut benar-benar bersih.

Daun Beluntas (Plucea Indica (L) Less) yang telah bersih lalu ditiriskan dalam wadah yang berlubang/ayakan hal ini dimaksudkan supaya air bisa menetes ke bawah dan daun Beluntas (Plucea Indica (L) Less) benar-benar terbebas dari air. Setelah 
daun Beluntas (Plucea Indica (L) Less) terbebas dari air maka dilakukannya pengovenan sehingga daun Beluntas (Plucea Indica (L) Less) menjadi simplisia, lalu masukan kedalam plastik klip yang tertutup rapat demi terjaganya kebersihan simplisia daun Beluntas (Plucea Indica (L) Less) tersebut. Daun yang sudah benarbenar kering dan terbebas dari air, lalu masuk ke tahapan selanjutnya pengovenan, agar proses pengeringan tidak terlalu memakan waktu yang lama.

Pengeringan bertujuan untuk meningkatkan daya tahan simplisia sehingga bisa disimpan dalam jangka waktu waktu yang lama. Setelah kering, simplisia ini kemudian dikemas dalam plastik klip yang tertutup rapat, hal ini bertujuan untuk menjaga kebersihan simplisia sehingga layak untuk digunakan pada tahap selanjutnya yaitu proses ekstraksi. Metode ekstraksi yang digunakan pada penelitian ini yakni infusa, dengan menggunakan pelarut air. Hal ini dikarenakan dalam pembuatan simping hanya airnya yang diambil yakni air hasil infusa daun Beluntas (Plucea Indica (L) Less) tersebut.

Pembuatan simping dilakukan dengan cara dicetak dan dibakar, adonannya sendiri terdiri dari tepung tapioka, tepung terigu, santan, garam, dan yang paling utama yakni air infusa daun Beluntas (Plucea Indica (L) Less). Pada saat pembuatan, diusahakan simping jangan sampai gosong, karena akan merusak penampilan dan tidak akan terlihat menarik. Hasil simping yang didapat yaitu sebanyak 900 gr atau sebanyak enam bungkus yang masing-masing berat pada setiap bungkus itu $150 \mathrm{gr}$.

Pengujian organoleptis sediaan selama 3 minggu merupakan tahap selanjutnya, dengan tujuan untuk menguji kestabilan sediaan dan memastikan tidak terjadinya perubahan bentuk, warna, bau, rasa maupun tumbuhnya jamur didalamnya. Pengujian dilakukan dengan menyimpan sediaan dalam dua tempat dengan suhu yang sama, yaitu di dalam ruangan yang mempunyai suhu berkisar dari $20-25^{\circ} \mathrm{C}$. Hasil yang didapat selama tiga minggu menunjukkan bahwa tidak ada perubahan dalam hal bentuk, warna, bau, rasa maupun tumbuhnya jamur pada sediaan tersebut diperkirakan karena pada tahap-tahapan pembuatan sudah sesuai peraturan, sehingga dapat dikatakan bahwa sediaan yang peneliti buat tahan selama tiga minggu. Pengujian organoleptis setelah 3 minggu pun dilakukan oleh peneliti untuk memastikan bahwa sediaan yang dibuat oleh peneliti lulus uji ketahanan sediaan lebih dari tiga minggu.

Penelitian ini merupakan suatu penelitian pengembangan yang berupa pembuatan simping dari bahan herbal yang dapat digunakan sebagai perawatan kesehatan. Bahan herbal yang digunakan yaitu daun Beluntas (Plucea Indica (L) Less) yang dibuat dalam bentuk cemilan sehat sebagai penggunaan dalam. Penelitian ini hanya terbatas melakukan pengujian organoleptis terhadap sediaan yang telah dibuat, meliputi pengamatan terhadap bentuk, warna, bau, rasa dan tumbuhnya jamur yang dilakukan selama 3 minggu.

\section{SIMPULAN}

Simping daun Beluntas (Plucea Indica (L) Less) yang komposisinya terdiri dari air infusa daun Beluntas (Plucea Indica (L) Less), tepung tapioka, tepung terigu, santan, dan garam ini dapat disimpan selama tiga minggu dengan keadaan fisik yang relatif tidak berubah. Simping ini dijadikan untuk perawatan kesehatan, semua kalangan bisa mengkonsumsinya mulai dari anak-anak, remaja, dewasa, hingga orangtua. Untuk penelitian selanjutnya disarankan melakukan penelitian lebih lanjut mengenai kemanfaatan cemilan sehat untuk perawatan kesehatan.

\section{DAFTAR PUSTAKA}

1. Ardiansyah, 2005. Daun Beluntas Sebagai Bahan Antibakteri dan Antioksidan http://www.beritaiptek.com. November 2010)

2. Sulistiyaningsih, 2009. Potensi Daun Beluntas (Plucea Indica L) sebagai inhibitor terhadap Pseudomonas aeruginosa dan Staphylococcus aureus. Fakultas Farmasi Universitas Padjajaran. Bandung.

3. Yuliarni, U. Lukmayani. 2016. Aktifitas Antifungi Ekstrak Daun Beluntas terhadap Candida Albicans. 
Journal of Holistic and $\mathrm{Health} \mathrm{Sciences}$ Vol.2, No.1, Januari-juni 2018 |35

Journal.uad.ac.id/index.php/Pharmacian ana, Vol.6, No.1, 2016: 89-94.

a/article/download/2684/pdf/pharmaci 